\title{
Daytime ozone and temperature variations in the mesosphere: a comparison between SABER observations and HAMMONIA model
}

\author{
S. Dikty ${ }^{1}$, H. Schmidt ${ }^{2}$, M. Weber ${ }^{1}$, C. von Savigny ${ }^{1}$, and M. G. Mlynczak ${ }^{3}$ \\ ${ }^{1}$ Institute of Environmental Physics, Bremen, Germany \\ ${ }^{2}$ Max-Planck-Institute for Meteorology, Hamburg, Germany \\ ${ }^{3}$ NASA Langley Research Center, Hampton, VA, USA
}

Received: 1 December 2009 - Published in Atmos. Chem. Phys. Discuss.: 29 January 2010

Revised: 28 July 2010 - Accepted: 20 August 2010 - Published: 6 September 2010

\begin{abstract}
This paper investigates the latest version 1.07 SABER (Sounding of the Atmosphere using Broadband Emission Radiometry) tropical ozone from the $1.27 \mu \mathrm{m}$ as well as from the $9.6 \mu \mathrm{m}$ retrieval and temperature data with respect to day time variations in the upper mesosphere. The processes involved are compared to day time variations of the three-dimensional general circulation and chemistry model HAMMONIA (Hamburg Model of the Neutral and Ionized Atmosphere). The results show a good qualitative agreement for ozone. The amplitude of daytime variations is in both cases approximately $60 \%$ of the daytime mean. During equinox the daytime maximum ozone abundance is for both, the observations and the model, higher than during solstice, especially above $0.01 \mathrm{hPa}$ (approx. $80 \mathrm{~km}$ ). The influence of tidal signatures either directly in ozone or indirectly via a temperature response above $0.01 \mathrm{hPa}$ can not be fully eliminated. Below $0.01 \mathrm{hPa}$ (photo-)chemistry is the main driver for variations. We also use the HAMMONIA output of daytime variation patterns of several other different trace gas species, e.g., water vapor and atomic oxygen, to discuss the daytime pattern in ozone. In contrast to ozone, temperature data show little daytime variations between 65 and $90 \mathrm{~km}$ and their amplitudes are on the order of less than $1.5 \%$. In addition, SABER and HAMMONIA temperatures show significant differences above $80 \mathrm{~km}$.
\end{abstract}

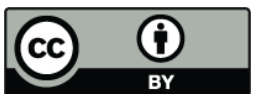

Correspondence to: S. Dikty (dikty@iup.physik.uni-bremen.de)

\section{Introduction}

The sun influences the thermal structure, dynamics, and chemistry of the Earth's middle atmosphere. If ultraviolet (UV) radiation levels alter, middle atmospheric ozone is affected as well as other trace gases formed by photolysis from a direct radiation effect and due to a dynamical response to solar variability (indirect effect). In particular, the response of ozone above $60 \mathrm{~km}$ to variations in UV radiation is not well established. In comparison with the 27-day solar rotation signal (e.g., Chen et al., 1997; Hood and Zhou, 1998; Ruzmaikin et al., 2007; Gruzdev et al., 2009; Dikty et al., 2010) and the 11-year solar cycle response (e.g., Haigh, 2003; Hood, 2004; Crooks and Gray, 2005; Soukharev and Hood, 2006; Marsh et al., 2007) in the middle atmosphere, the daytime variation of UV radiation inflicts a by far greater response in mesospheric ozone.

In the following we will refer to "daytime" variations as to (ozone and temperature) variations between sunrise and sunset, i.e. in the tropics approx. between $06: 00 \mathrm{~h}$ and 18:00 $\mathrm{h}$ solar local time. The daytime patterns will be the main focus of this paper. The term "diurnal" will be reserved for variations on the $24 \mathrm{~h}$ time scale. The amplitude of daytime ozone variations in the upper mesosphere from sunrise to sunset is about $60 \%$ of the daytime mean with extreme ozone values between 0.01 to $0.4 \mathrm{ppm}$ at $77.5 \mathrm{~km}$ and 0.1 to more than $1 \mathrm{ppm}$ for altitudes $85 \mathrm{~km}$ and above.

In this study we use version 1.07 SABER ozone and temperature vertical profiles from 2003 to 2006 to derive daytime variations in the tropical upper mesosphere and to compare them with the output of the HAMMONIA model and to previous studies. In addition, version 1.07 SABER ozone data

Published by Copernicus Publications on behalf of the European Geosciences Union. 
are compared to the previous version 1.06 data that was used in Huang et al. (2008a), especially since the ozone retrieval at $1.27 \mu \mathrm{m}$ was updated with respect to non-LTE processes, and the $9.6 \mu \mathrm{m}$ ozone retrieval was improved by reducing the physical quenching rates of the ozone vibrational levels by a factor of 3. In addition to Huang et al. (2008a), we also include SABER temperature data in our analysis and discuss our results with respect to the chemistry responsible for the daytime pattern from HAMMONIA ozone, temperature, and other trace gases. Another focus of this paper is the introduction to the relatively easy method of reassigning local time to measurements in order to retrieve daytime variations. In Sect. 2 we will first summarize the data sources before we will briefly explain in Sect. 3 the methods used to extract the daytime pattern in ozone and temperature. The presentation of the results (Sect. 4) and their discussion in Sect. 5 is followed by a summary in Sect. 6 .

An early study by Vaughan (1984) summarizes the basics of mesospheric ozone chemistry. He used ozone data from rocket-borne instrumentation and temperature data from SAMS on Nimbus-7 and compared these with the output of a radiative photochemical model. Other early references to mesospheric ozone chemistry are the papers by Allen et al. (1984a, b), wherein they pointed out the significance of oxygen and hydrogen-containing species and the temperature profile on the diurnal variability of ozone. Data used in these papers are from ground-based and rocket borne instrumentation at mid-latitudes. Several other studies investigated diurnal ozone variations in the mesosphere, including nighttime, with satellites (Ricaud et al., 1996; Marsh et al., 2002; Huang et al., 2008a; Smith et al., 2008) and ground-based observations (Connor et al., 1994; Haefele et al., 2008). Ricaud et al. (1996) also compared their observations with model results. Ground-based observations done in the Bordeaux area were compared to a one-dimensional photochemical model by Schneider et al. (2005). They clearly saw a diurnal pattern and a semi-annual oscillation (SAO) signal above $50 \mathrm{~km}$ altitude. All of the above mentioned studies show that with nightfall when the photo-destruction of ozone stops and ozone quickly reaches a high nighttime equilibrium in the mesosphere. The models used by Ricaud et al. (1996) and Sinnhuber et al. (2003) did not show any variations during night, and observations showed little to no variations.

Marsh et al. (2002) studied diurnal ozone variations from the High Resolution Doppler Imager (HRDI) on board the Upper Atmosphere Research Satellite (UARS) in the altitude range between 70 and $95 \mathrm{~km}$. They attributed the increase in ozone in the afternoon in the upper mesosphere to the migrating diurnal tide. Air that is rich in atomic oxygen is believed to be pumped down from the lower thermosphere and to form ozone on recombination with molecular oxygen. SABER temperature data have been used, e.g., by Zhang et al. (2006) and Mukhtarov et al. (2009) to study tidal signatures between 20 and $120 \mathrm{~km}$ altitude within $\pm 50^{\circ}$ latitude.
The solar diurnal tide has also been investigated by Achatz et al. (2008) who utilized a combination of HAMMONIA and a linear model.

Smith et al. (2008) were recently reporting on high ozone values at the nighttime mesopause observed in SABER version 1.07 ozone derived from $9.6 \mu \mathrm{m}$ radiance. They used a simplified model of the diurnal migrating tide to show that the high nighttime ozone values (up to $40 \mathrm{ppm}$ ) are a result of an upward motion of air low in atomic hydrogen and atomic oxygen combined with low temperatures, as a result of adiabatic cooling.

The paper by Huang et al. (2008a) can be seen as a precursor to the present study. They reported on SABER version 1.06 diurnal ozone variations (derived from $9.6 \mu \mathrm{m}$ radiance) over $24 \mathrm{~h}$ with the help of a two-dimensional Fourier least squares analysis. They were able to determine the diurnal variation as a function of latitude (up to $48^{\circ}$ ), altitude and day of year. The analysis was however limited to at least one year of data. Beig et al. (2008) gave an overview of the temperature response to solar activity in the mesosphere and lower thermosphere. They assumed that the temperature response to solar activity is mainly due to the vertical distribution of chemically active gases near the mesopause and due to changes in the UV radiation.

\section{Data sources}

\subsection{SABER satellite data}

The TIMED (Thermosphere, Ionosphere, Mesosphere, Energetics and Dynamics) satellite has been launched on 12 July, 2001 (Russel III et al., 1999; Remsberg et al., 2008). It circles the Earth in a low orbit of $628 \mathrm{~km}$ mean altitude with an inclination of $74^{\circ}$. The TIMED satellite is in a non-sun synchronous or drifting orbit with a mean orbital time of 97 min. The equator crossing time shifts by approx. $12 \mathrm{~min}$ per day.

SABER on board TIMED is an infrared spectrometer measuring limb emission with a spectral range from $1.27 \mu \mathrm{m}$ to $16.9 \mu \mathrm{m}$. The time required to make one "up" or "down" scan of the limb is slightly less than one minute. The instrument scans up to about $400 \mathrm{~km}$ in altitude, although the only channel that measures above $180 \mathrm{~km}$ tangent height is the NO channel at $5.3 \mu \mathrm{m}$. The vertical resolution is approximately $2 \mathrm{~km}$ and the instrument has a vertical sampling of $0.4 \mathrm{~km}$ (Russel III et al., 1999).

The scanning direction of the SABER instrument is perpendicular to the flight direction of TIMED. Once approximately every 60 days, the TIMED satellite performs a yaw maneuver reversing the scanning direction of SABER by $180^{\circ}$. This measuring geometry limits the latitudinal coverage to $83^{\circ} \mathrm{S}$ to $52^{\circ} \mathrm{N}$ and $52^{\circ} \mathrm{S}$ to $83^{\circ} \mathrm{N}$, respectively. Continuous time series for high latitudes are therefore not available. Figure 1 shows the spatial coverage for one day of 
a) SABER global coverage, 25 March 2003

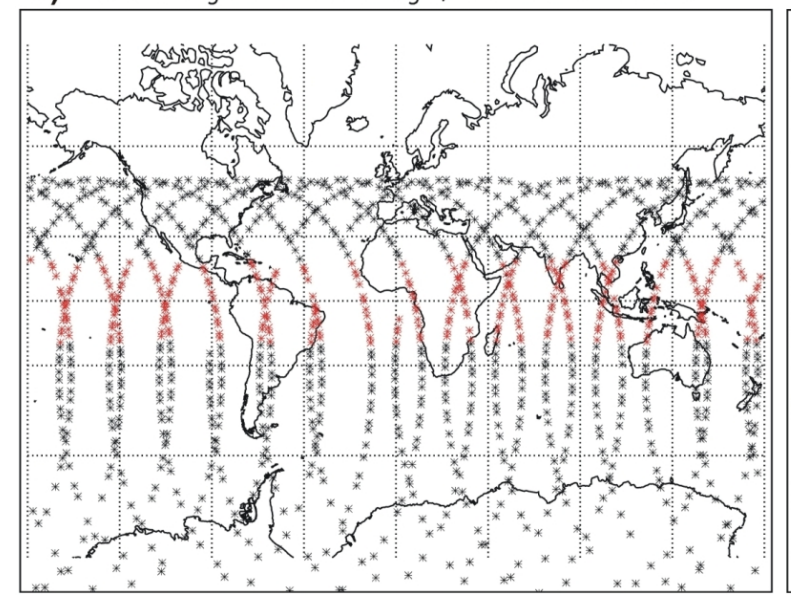

b) SABER global coverage, 25 May 2003

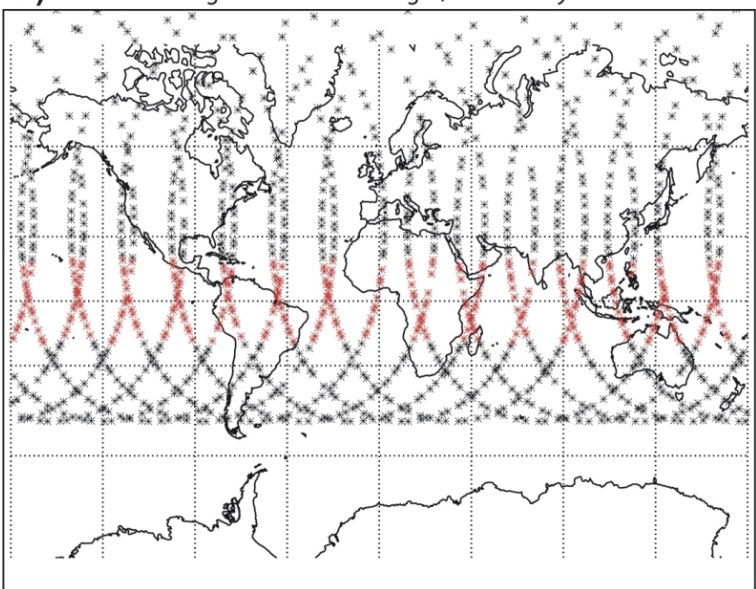

Fig. 1. Example of daily global coverage of SABER measurements. On 25 March (left panel), 2003, the instrument was facing south and on 25 May (right panel), 2003, SABER was facing north. Each asterisk resembles one profile. Profiles between $20^{\circ} \mathrm{S}$ and $20^{\circ} \mathrm{N}$ are highlighted in red.

SABER measurements on 25 March, 2003, pointing south and on 25 May, 2003, pointing north. The overall yield is roughly 40000 profiles per month as SABER solely performs limb measurements.

Many parameters related to the odd-oxygen photochemistry and the energy budget of the mesosphere can be derived from measurements of the dayglow emissions and are used to infer ozone from the $1.27 \mu \mathrm{m}$ airglow as described in Mlynczak et al. (2007). Depending on wavelength $(320 \mathrm{~nm}<$ $\lambda<1180 \mathrm{~nm}$ ) the photochemical destruction of ozone can lead to molecular oxygen in its ground state (Eq. 1), at wavelengths shortward of $320 \mathrm{~nm}$, and to oxygen in its first exited state (Eq. 2). The de-excitation leads to airglow emissions at $1.27 \mu \mathrm{m}$ (Eq. 3) which can be detected by SABER and other spectrometers in orbit, e.g., SCIAMACHY aboard ENVISAT (Bovensmann et al., 1999) and OSIRIS on Odin (Llewellyn et al., 2004):

$$
\begin{aligned}
& \mathrm{O}_{3}+h v(\lambda>320 \mathrm{~nm}) \rightarrow \mathrm{O}_{2}\left({ }^{3} \Sigma\right)+\mathrm{O}\left({ }^{3} \mathrm{P}\right) \\
& \mathrm{O}_{3}+h v(\lambda<320 \mathrm{~nm}) \rightarrow \mathrm{O}_{2}\left({ }^{1} \Delta\right)+\mathrm{O}\left({ }^{1} \mathrm{D}\right) \\
& \mathrm{O}_{2}\left({ }^{1} \Delta\right) \rightarrow \mathrm{O}_{2}\left({ }^{3} \Sigma\right)+h v(1.27 \mu \mathrm{m})
\end{aligned}
$$

In addition to the retrieval of ozone at $1.27 \mu \mathrm{m}$ that is limited to daytime, the thermal emissions of ozone at $9.6 \mu \mathrm{m}$ from vibration-rotational energy release can be detected by SABER as described in Rong et al. (2008). The retrieval in the $9.6 \mu \mathrm{m}$ region permits measurements of ozone not only during daylight but at night as well and the vertical coverage is not limited to the mesosphere and lower thermosphere. Huang et al. (2008a) studied diurnal variations of ozone retrieved at $9.6 \mu \mathrm{m}$. Differences to Huang et al. (2008a) will be highlighted throughout this study. One of which is the emphasis on the daytime (06:00 $\mathrm{h}-18: 00 \mathrm{~h}$ solar local time) ozone pattern, in addition to comparisons to the HAMMONIA model. In this paper we will use ozone data retrieved at $1.27 \mu \mathrm{m}$ and at $9.6 \mu \mathrm{m}$, and we also include temperature data available from SABER. The temperature is retrieved using the spectral information from the two $\mathrm{CO}_{2}$ channels at $14.9 \mu \mathrm{m}$ and $15.2 \mu \mathrm{m}$ (Remsberg et al., 2004).

\subsection{Description of HAMMONIA model}

In this study we use the output from the three-dimensional general circulation and chemistry model HAMMONIA (Schmidt et al., 2006) to compare to SABER observations. HAMMONIA treats atmospheric dynamics, radiation and chemistry interactively. It was developed as an extension of the atmospheric general circulation model MAECHAM5 (Giorgetta et al., 2006; Manzini et al., 2006) and additionally accounts for radiative and dynamical processes in the upper atmosphere. HAMMONIA includes 153 gas phase reactions and 48 chemical compounds. It is a spectral model with (in the current configuration) triangular truncation at wave number 31 (T31) and with 67 levels between the surface and $1.7 \times 10-7 \mathrm{hPa}(\sim 250 \mathrm{~km})$. The model includes a full dynamic and radiative coupling with the MOZART3 chemical module (Kinnison et al., 2007). In addition, it accounts for solar heating in the ultraviolet and extreme ultraviolet wavelength regime, a non-LTE radiative (i.e. radiative cooling) scheme, energy deposition and eddy diffusion generated by gravity wave breaking, vertical molecular diffusion and conduction, and a simple parameterization of electromagnetic forces in the thermosphere. The processing of the model output is described in Sect. 3. 


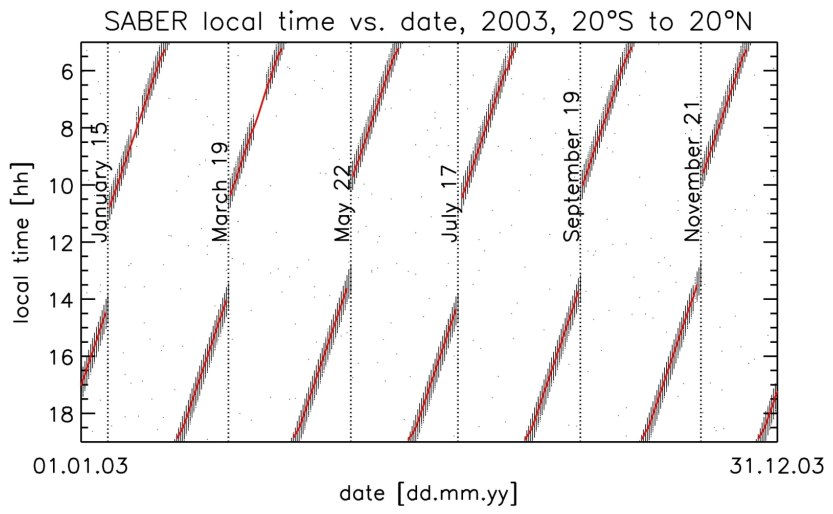

Fig. 2. Distribution of solar local times of SABER measurements between $20^{\circ} \mathrm{S}$ and $20^{\circ} \mathrm{N}$ for the year 2003. Each dot represents one profile. The vertical dotted lines with dates indicated mark yaw maneuvers. The red line shows daily mean of the solar local time of measurements.

\section{Data analysis}

\subsection{SABER ozone and temperature data processing}

All daytime time series have a strong signal with a periodicity of approximately 60 days which corresponds to the drift of measurements with local time and the yaw maneuver TIMED is performing. In the tropics this drift in local time is plotted in Fig. 2 for 2003. Yaw maneuvers are indicated as vertical dotted lines. Each dot in the plot represents a single profile and the red solid line indicates the mean local time of measurement. The fairly small spread of about half an hour gives us the uncertainty with which we determine the mean local time. The variability of the solar local time of approximately half an hour on a given day is mainly due to the fact that the solar local time is slightly different at each latitude in the tropics (movement of the satellite). So by reassigning each day's area weighted zonal mean profile to its mean local time of measurement (with an error of approximately $30 \mathrm{~min}$ around the mean) the analysis of daytime variations becomes possible. The daytime variation is derived from data covering 60 days of measurements between yaw maneuvers. Due to the properties of the TIMED orbit measurements between 11:00 $\mathrm{h}$ and 13:00 $\mathrm{h}$ solar local time are not possible.

The SABER ozone profiles retrieved from the $1.27 \mu \mathrm{m}$ and $9.6 \mu \mathrm{m}$ radiometer measurements as well as temperature profiles were interpolated to a regular height grid of $0.5 \mathrm{~km}$ using spline interpolation, accounting for errors in the mixing ratios. All profiles were also gritted in the same fashion to a logarithmic pressure scale with an approximate height step of $1 \mathrm{~km}$. Up to 200 profiles per day from within $20^{\circ} \mathrm{S}$ to $20^{\circ} \mathrm{N}$ were available for the calculation of an area weighted zonal mean profile per day. Days with less than 10 profiles were treated as days with no data. At each pressure level outliers in the time series were identified as being outside the $3 \sigma$

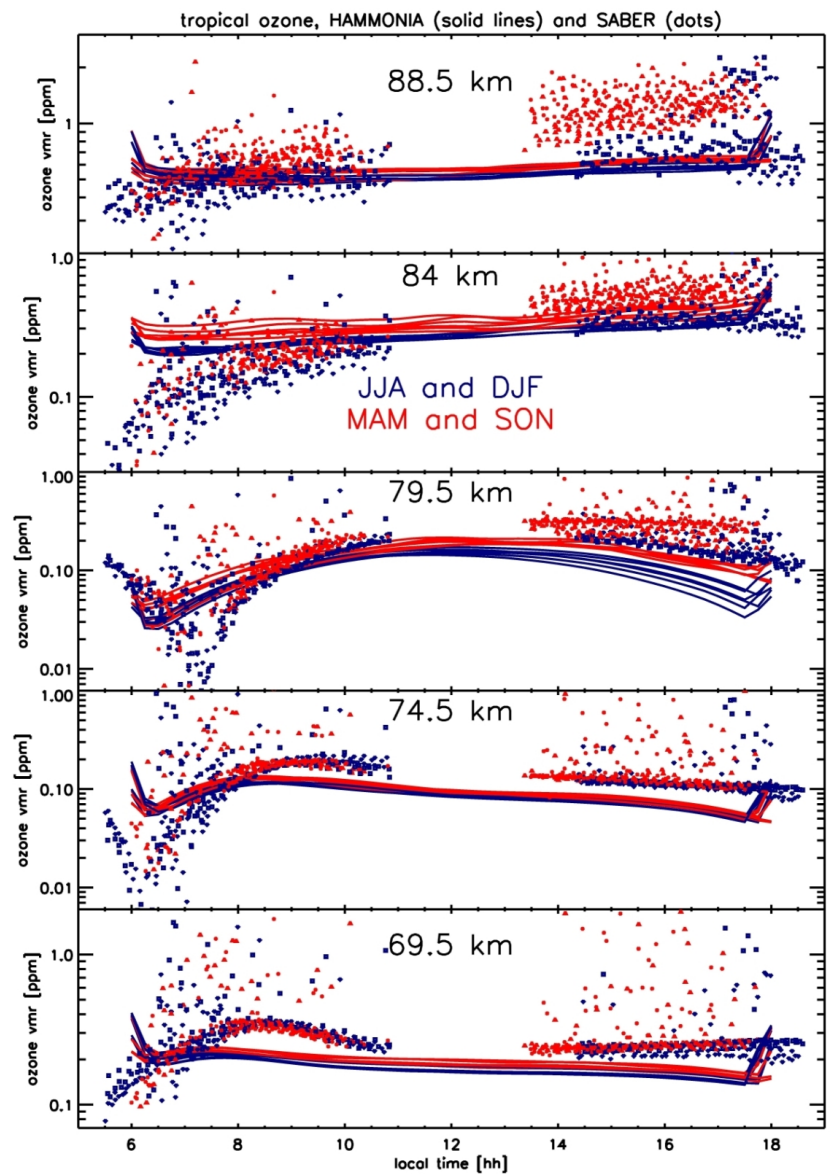

Fig. 3. SABER (dots) and HAMMONIA (solid lines) daytime ozone $(1.27 \mu \mathrm{m}$ retrieval) variations at $69.5,74.5,79.5,84$, and $88.5 \mathrm{~km}$ (i.e. $0.03,0.02,0.01,0.0061$, and $0.003 \mathrm{hPa}$ ) sorted by month $\left(20^{\circ} \mathrm{S}\right.$ and $\left.20^{\circ} \mathrm{N}\right)$. Months close to equinox are highlighted in red and months close to solstice are marked in blue.

value of the whole time series. Small data gaps were closed by the use of a spline interpolation. Fortunately, there were no large data gaps from 2003 to 2006.

The resulting daytime variation of ozone is shown in Fig. 3 at geometric heights of $69.5,74.5,79.5,84$, and $88.5 \mathrm{~km}$ (dots) in absolute quantities of volume mixing ratio. Each dot represents a daily area weighted zonal mean value. The daytime variations of ozone are also shown in Figs. 4 and 5 (color coding). Here the variation is given as deviation from the daytime (06:00 $\mathrm{h}$ to $18: 00 \mathrm{~h}$ ) mean in $\%$ for pressure levels between 0.1 to $0.001 \mathrm{hPa}$. Averaged values were computed in $30 \mathrm{~min}$ steps. SABER temperature anomalies can be seen in Fig. 6 (color coding).

\subsection{HAMMONIA model output processing}

The HAMMONIA model output used in this study is a 20 year-average from a timeslice simulation for present day greenhouse gas concentrations and solar minimum 

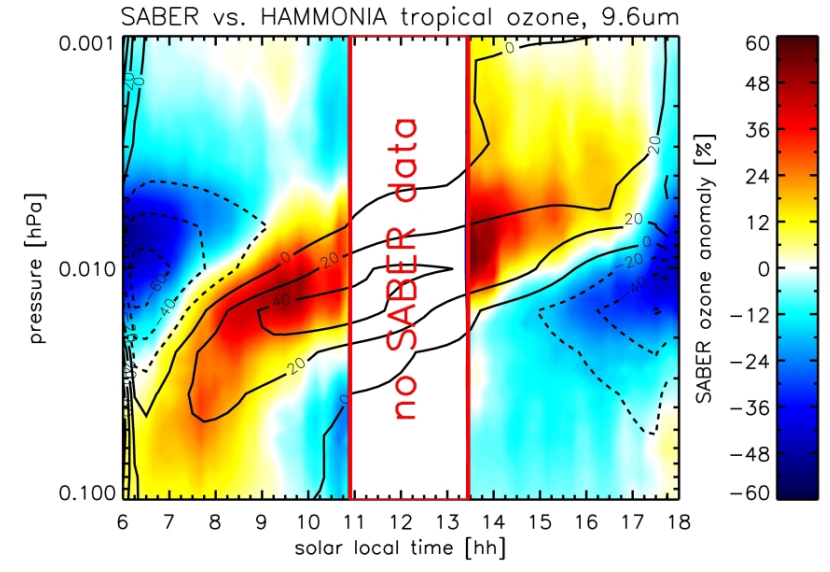

Fig. 4. SABER (retrieved at $9.6 \mu \mathrm{m}$, color coding) and HAMMONIA (contour lines) daytime ozone variations (deviation from the daytime mean in \%) between 0.1 and $0.001 \mathrm{hPa}$.

conditions as described by Schmidt et al. (2006). The output is available covering all longitudes in $3.75^{\circ}$-steps and all latitudes in $3.75^{\circ}$-steps. There are 67 model levels in HAMMONIA ranging from the surface to $1.7 \times 10-7 \mathrm{hPa}(\sim 250 \mathrm{~km})$. The vertical resolution in the mesosphere is about $3 \mathrm{~km}$. Along latitude circles all solar local times are covered, which makes it possible to derive diurnal and daytime variations. As the 3-D model output is available each $3 \mathrm{~h}$, results presented here for specific local times are calculated as an average of 8 locations spaced by 45 degrees of longitude. All latitude steps between $20^{\circ} \mathrm{S}$ and $20^{\circ} \mathrm{N}$ were chosen to derive an area weighted meridional mean profile. Sunrise and sunset were identified by the sharp decrease and increase in ozone at $0.01 \mathrm{hPa}$, respectively, at the equator and defined as 06:00 $\mathrm{h}$ and 18:00 $\mathrm{h}$ solar local time, accordingly. HAMMONIA ozone and temperature daytime variations are shown in Figs. 4, 5 and 6 along with SABER ozone and temperature observations. Figure 7 shows model results for atomic hydrogen, water vapor, hydroxyl, nitric oxide, atomic oxygen, and molecular oxygen in terms of a relative deviation from the daytime mean in $\%$.

\section{Results}

As can be seen in Figs. 4 and 5, SABER and HAMMONIA ozone have distinct and very similar patterns of daytime variation between 0.1 and $0.001 \mathrm{hPa}$. SABER ozone results are color coded and the HAMMONIA model results are drawn with line contours. While Fig. 4 shows the results for ozone retrieved at $9.6 \mu \mathrm{m}$, Fig. 5 shows the results for ozone retrieved at $1.27 \mu \mathrm{m}$. For both retrievals and model output, ozone variation from sunrise to sunset can be up to $60 \%$ from the daytime mean value. The daytime mean is altitude dependent and considers all years (2003-2006). Both observation

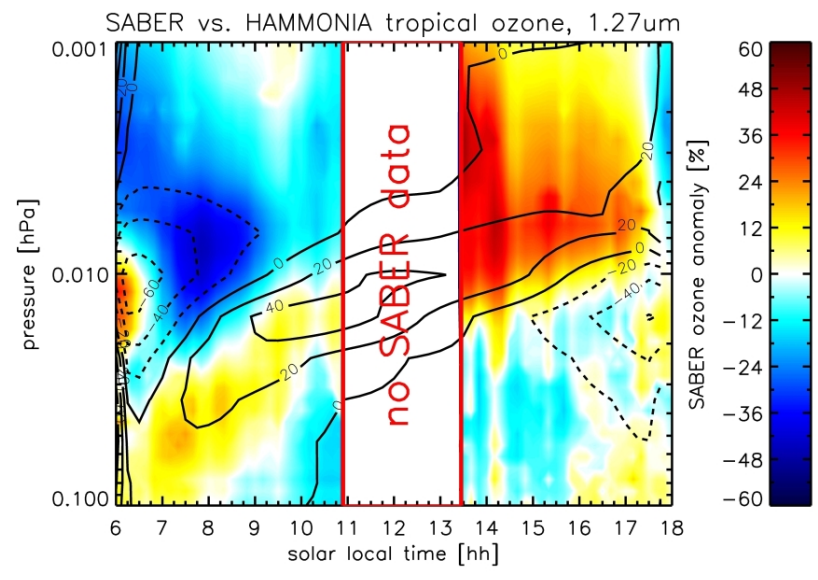

Fig. 5. Same as Fig. 4, but for SABER $1.27 \mu \mathrm{m}$ retrieval.

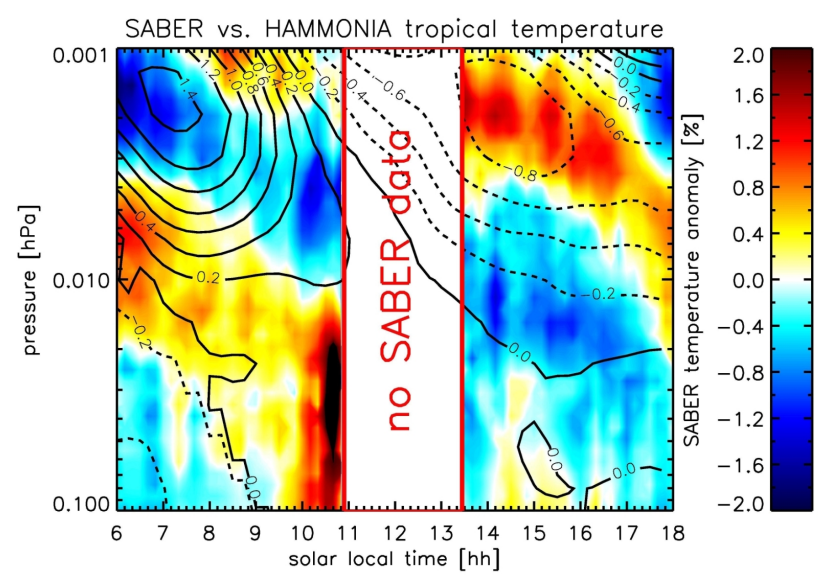

Fig. 6. SABER (color coding) and HAMMONIA (contour lines) daytime temperature variations (deviation from the daytime mean in $\%$ ) between 0.1 and $0.001 \mathrm{hPa}$.

and model have in common that below about $0.01 \mathrm{hPa}$ ozone values peak in the morning and decrease towards the afternoon. This peak shifts towards the afternoon with increasing altitude.

SABER and HAMMONIA ozone show good agreement in the daytime pattern as shown in Figs. 4, 5 and 8. The maximum daytime peak anomaly observed at $0.05 \mathrm{hPa}(\sim 70 \mathrm{~km})$ in the morning shifts its altitude to about $0.007 \mathrm{hPa}(\sim 80 \mathrm{~km})$ in the afternoon. This daytime shift is in very good agreement with the model, however the peak anomaly reaches a maximum of $40-50 \%$ of the daytime mean, which is higher than HAMMONIA (30-40\%). Negative anomalies are observed in the early morning hours at $0.007 \mathrm{hPa}$ and in the late afternoon near $0.015 \mathrm{hPa}$ in quite good agreement with the model (Fig. 4). In contrast the $1.27 \mu \mathrm{m}$ retrieval (Fig. 5) does not show this negative anomaly, which could be a SABER retrieval artifact due to twilight conditions (Zhu et al., 2007). 

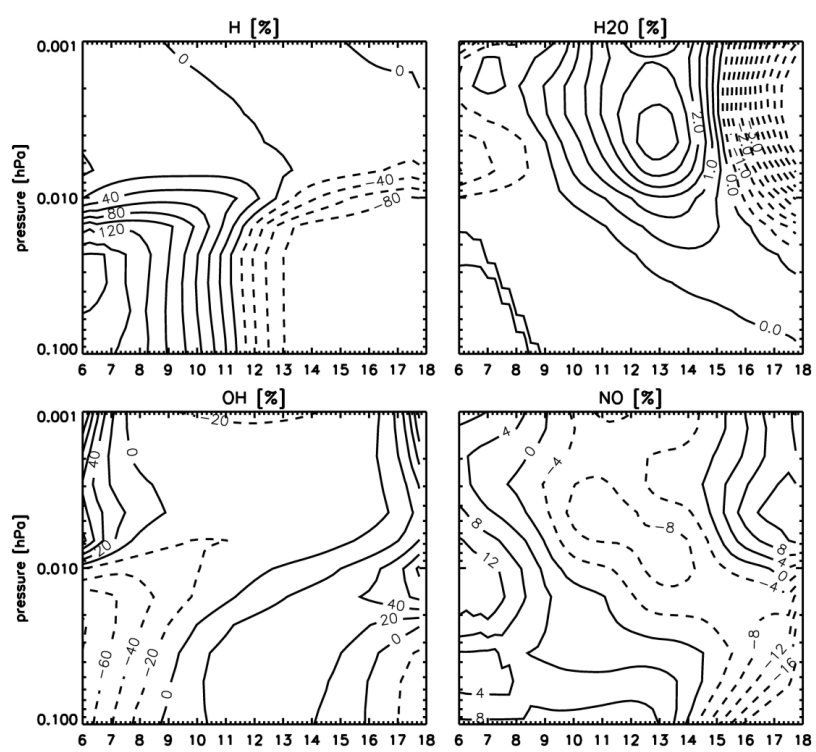

$0[\%]$
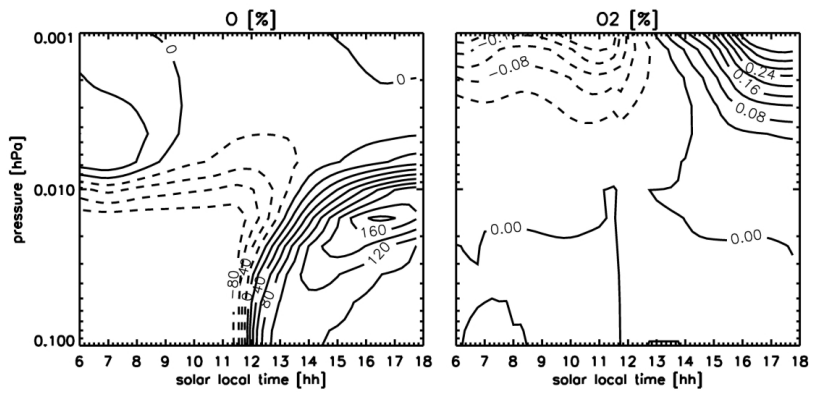

Fig. 7. HAMMONIA daytime variations of atomic hydrogen, water vapor (top row, left to right), hydroxyl, nitric oxide (middle row, left to right), atomic oxygen, and oxygen (bottom row, left to right) between 0.1 and $0.001 \mathrm{hPa}$, given as deviation from the daytime mean in $\%$.

The positive anomaly in the morning hours is also much weaker for the $1.27 \mu \mathrm{m}$ retrieval $(\sim 10 \%)$ than for the $9.6 \mu \mathrm{m}$ $(\sim 40 \%)$. Generally the agreement with the model is better for the thermal infrared retrieval.

In the case of temperature, the daytime behavior of SABER and HAMMONIA is out of phase for pressure levels above $0.01 \mathrm{hPa}$ (Fig. 6). SABER observes low temperatures in the morning and high values in the afternoon, whereas HAMMONIA predicts high values in the morning and low temperatures in the afternoon. Below $0.01 \mathrm{hPa}$ the agreement is better, yet HAMMONIA does not predict the spurious peak just before the SABER data gap at noon. This might be an artifact in the observations due to averaging effects close to the data gap around noon.

The daytime ozone variations depend on the season as is shown in Fig. 3. Especially in the afternoon and above $80 \mathrm{~km}$, ozone reaches up to about $1 \mathrm{ppm}$ in March, April, and May and again in September, October, and November, close to the equinox with increased solar input into the mesosphere. A similar seasonal dependence (albeit with weaker

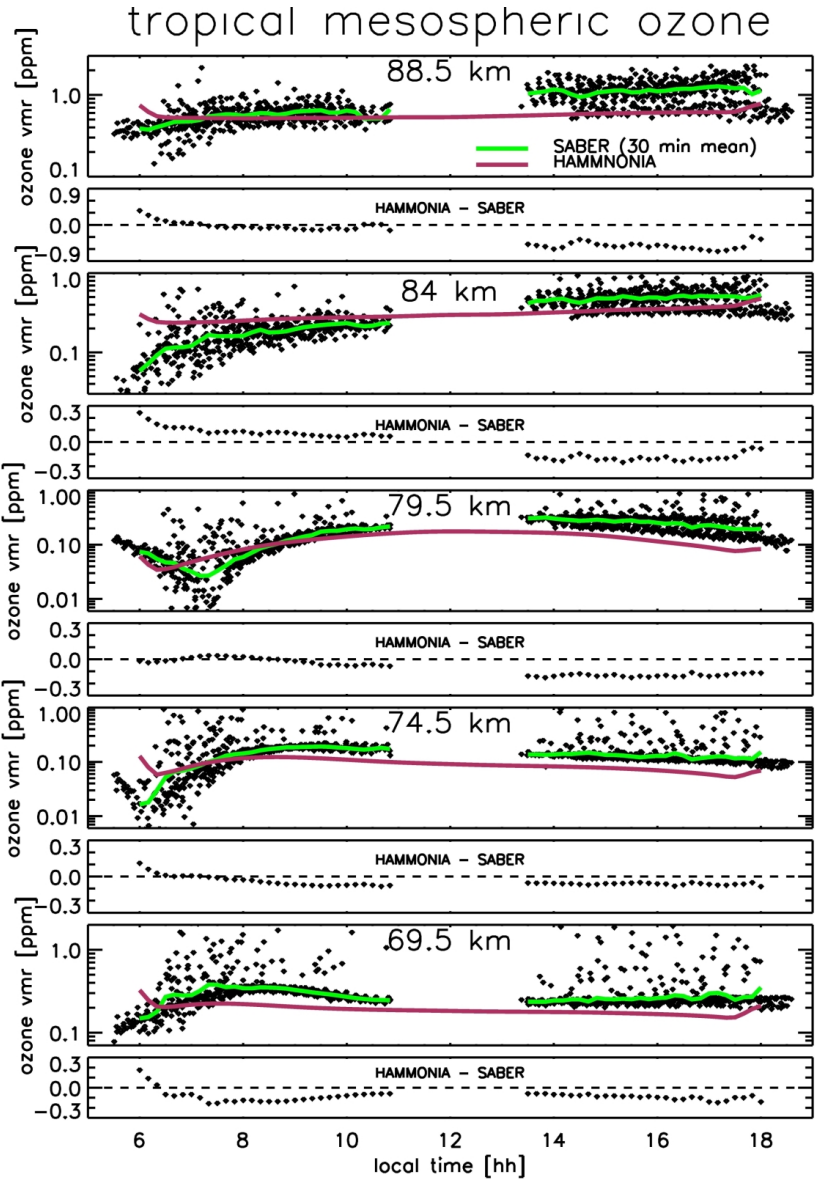

Fig. 8. Daytime ozone $(1.27 \mu \mathrm{m}$ retrieval $)$ variations as seen by SABER (dots) and HAMMONIA (red solid line) at 69.5 74.5 79.5, 84 , and $88.5 \mathrm{~km}$ (i.e. $0.03,0.02,0.01,0.0061$, and $0.003 \mathrm{hPa}$ ). A 30 min running mean was calculated for SABER ozone (green solid line) and the difference to HAMMONIA was plotted below each plot.

amplitude at high altitudes) is also produced by the HAMMONIA model. Another point is that the ozone minima in the morning do not occur at the same time at 79.5 and $74.5 \mathrm{~km}$. SABER observes the minimum approximately 30 60 min later than HAMMONIA.

\section{Discussion}

Huang et al. (2008a) reported on diurnal patterns from $9.6 \mu \mathrm{m}$ data, version 1.06, including day and night time ozone values. Their method to obtain the diurnal pattern is to perform a least squares estimate of a two-dimensional Fourier series with at least one year of data. With the coefficients from the least squares fit the diurnal variations can be calculated. So, the method is different but the daytime patterns of Huang et al. (2008a) and ours are qualitatively in agreement as described in the previous chapter. The main distinction of our method is the focus on daytime rather than diurnal 
variations, whereas Huang et al. (2008a) concentrated on the ozone shifts at daybreak and nightfall.

The seasonal variation in ozone that can be seen in Fig. 3 is likely due to the variation of the angle of the incident light. At equinox the sun has the shortest path through the atmosphere in the tropics and thus the strongest potential to photodissociate molecular oxygen. At solstice these light paths are slightly longer in the tropics. Huang et al. (2008b) saw large amplitudes in the temperature semi-annual oscillation (SAO) at 75 and again at $85 \mathrm{~km}$ with a distinct minimum in between, and small SAO amplitudes below $80 \mathrm{~km}$, above rising to peak at $95 \mathrm{~km}$. So, a temperature dependency of the ozone SAO in the lower thermosphere cannot be ruled out which on the other hand is linked to the amplitude of the solar diurnal tide. Tidal amplitudes are stronger during equinox than during solstice.

We have shown the good agreement between the SABER and HAMMONIA daytime ozone pattern. In the following, we discuss this pattern with the help of other simulated species (e.g., H, O and OH). Ricaud et al. (1996) explain rising ozone values below $0.01 \mathrm{hPa}$ in the morning with the increased photo-dissociation of $\mathrm{O}_{2}$ and consequently with a higher production of $\mathrm{O}_{3}$ due to the high abundance of $\mathrm{O}$ radicals. Figure 7 shows the daytime pattern of $\mathrm{O}$ radicals between 0.1 and $0.001 \mathrm{hPa}$ (i.e., 65 to $95 \mathrm{~km}$ ) as seen by HAMMONIA. The amplitude rises as high as $160 \%$ from the daytime mean in the afternoon slightly below $0.01 \mathrm{hPa}$, where HAMMONIA ozone reaches its minimum. The decrease of ozone towards the afternoon below approximately $0.01 \mathrm{hPa}$ is assumed by Ricaud et al. (1996) to have its origin in the $\mathrm{HO}_{\mathrm{x}}$ catalytic cycles and the net destruction of ozone. HAMMONIA results of the daytime pattern show increasing values of $\mathrm{OH}$ and decreasing levels of atomic hydrogen below $0.01 \mathrm{hPa}$ towards the afternoon (Fig. 7). Above $0.01 \mathrm{hPa}$ other mechanisms must be of importance because the $\mathrm{O}$ and $\mathrm{H}$ radical abundances show almost no daytime pattern. Although we see daytime patterns in $\mathrm{H}_{2} \mathrm{O}$ and $\mathrm{O}_{2}$, the amplitude is rather small compared to $\mathrm{O}, \mathrm{OH}$ and $\mathrm{H}$. Also compared to $\mathrm{O}, \mathrm{H}$ and $\mathrm{OH}, \mathrm{NO}$ is the only shown species with strong daytime variations that does not have different amplitudes below and above $0.01 \mathrm{hPa}$, which indicates that for the mechanisms involved no distinction can be made between both altitude regions. According to Marsh et al. (2002), the shift of the ozone maximum towards late afternoon with increasing altitude, is accounted for by the temperature (altitude) dependent production rate of $\mathrm{HO}_{\mathrm{x}}$ and the associated ozone loss. Notice that there is a sharp edge towards low values in the observational data below $0.01 \mathrm{hPa}(\sim 80 \mathrm{~km})$ and some data are scattered to higher volume mixing ratios (Fig. 8). This lower boundary may be attributed to an upper limit in $\mathrm{H}_{2} \mathrm{O}$ abundances around $75-80 \mathrm{~km}$. An anti-correlation at these heights between $\mathrm{O}_{3}$ and $\mathrm{HO}_{x}$ has been concluded by Marsh et al. (2003) after having investigated data from the Halogen Occultation Experiment (HALOE).
Marsh et al. (2002) suggested that the solar diurnal tide "pumps" down atomic oxygen for the ozone production in the afternoon $(>85 \mathrm{~km})$. It is interesting to note that the daytime variation of ozone is well reproduced by HAMMONIA in contrast to the temperature that is not. This may indicate that chemistry itself may have a larger impact on the abundance of ozone rather than transport affects involving the lower thermosphere. The model, however, underestimates ozone in the afternoon above approximately $0.01 \mathrm{hPa}$, so the remaining difference could be attributed to solar tides. The minimum early in the morning is caused by the direct photolysis of ozone before enough atomic oxygen is produced to counteract the ozone destruction. It is also assumed by Marsh et al. (2002) that the rise of ozone in the morning hours is due to tides transporting ozone rich air from below. At $0.01 \mathrm{hPa}$ tropical ozone reaches its minimum. At the end of the day ozone rises to its high nighttime equilibrium shortly after sunset, the photochemistry being shut off.

Concerning tides, it is interesting to note that Achatz et al. (2008) have analyzed solar diurnal tides in HAMMONIA and found in general a good agreement with observed tides both in amplitude and in phase. The amplitude of the migrating diurnal tide in the equatorial region was however analyzed to be smaller than inferred from SABER data by Zhang et al. (2006). This supports our conclusion from above concerning the too low afternoon ozone concentrations above $0.01 \mathrm{hPa}$.

The amplitudes for temperatures from SABER observations and HAMMONIA model are relatively small. They only deviate about $1-1.5 \%$ (i.e. $1.2-2 \mathrm{~K}$ ) from the mean at maximum. It remains to be explained why model and observations show a different sign in the daytime pattern. Despite the general similarity of tidal patterns in HAMMONIA and observations as stated by Achatz et al. (2008), our comparison of temperature data suggests a difference in the vertical wavelength of tides in HAMMONIA and SABER. However, the exact analysis of the tides in HAMMONIA is not subject of this study.

\section{Summary}

Within this study we have compared SABER measurements and HAMMONIA model simulations of upper mesospheric daytime ozone and temperature variations in the tropics between $20^{\circ} \mathrm{S}$ and $20^{\circ} \mathrm{N}$.

HAMMONIA and SABER daytime ozone variations show a qualitatively good agreement, particularly for the $9.6 \mu \mathrm{m}$ retrieval. As the agreement is worse in the case of temperature, this suggests that the daytime ozone variations are mainly driven by (photo)-chemical processes and less influenced by transport. The underestimation of HAMMONIA ozone above $0.01 \mathrm{hPa}$ in the afternoon may be due to tidal amplitudes being too weak and associated weak downward transport of air rich in atomic oxygen. 
Daytime ozone values above $0.01 \mathrm{hPa}$ are higher close to equinox than close to solstice. Volume mixing ratios can even go as high as $1-1.5 \mathrm{ppm}$ in the afternoon for heights above $85 \mathrm{~km}$. Upcoming SABER version 1.08 data will also include water vapor, which will be helpful to constrain the $\mathrm{HO}_{\mathrm{x}}$ budget and its influence on daytime ozone.

Acknowledgements. We thank the SABER science team for providing data used in this study. This work was funded within the SOLOZON project as part of the German national CAWSES (Climate and Weather of the Sun-Earth-System) priority program. The numerical simulations with HAMMONIA have been performed at the German Climate Computing Center (DKRZ).

Edited by: F.-J. Lübken

\section{References}

Achatz, U., Grieger, N., and Schmidt, H.: Mechanisms controlling the diurnal solar tide: Analysis using a GCM and a linear model, J. Geophys. Res., 113, A08303, doi:10.1029/2007JA012967, 2008.

Allen, M., Lunine, J., and Yung, Y.: The Vertical Distribution of Ozone in the Mesosphere and Lower Thermosphere, J. Geophys. Res., 89, 4841-4872, 1984.

Allen, M., Lunine, J., and Yung, Y.: Correction to 'The Vertical Distribution of Ozone in the Mesosphere and Lower Thermosphere' by M. Allen, J. I. Lunine, and Y. L. Yung, J. Geophys. Res., 89, 11827-11827, 1984.

Beig, G., Scheer, J., Mlynczak, M. G., and Keckhut, P.: Overview of the temperature response in the mesosphere and lower thermosphere to solar activity, Rev. Geophys., 46, RG3002, doi:10.1029/2007RG000236, 2008.

Bovensmann, H., Burrows, J. P., Buchwitz, M., Frerick, J., Noël, S., Rozanov, V. V., Chance, K. V., and Goede, A. P. H.: SCIAMACHY: Mission Objectives and Measurement Modes, J. Atmos. Sci., 56, 127-150, 1999.

Chen, L., London, J., and Brasseur, G.: Middle atmospheric ozone and temperature responses to solar irradiance variations over 27day periods, J. Geophys. Res., 102, 29957-29979, 1997.

Connor, B. J., Siskind, D. E., Tsou, J. J., Parish, A., and Remsberg, E. E.: Ground-based microwave observations of ozone in the upper stratosphere and mesosphere, J. Geophys. Res., 99, 1675716770, 1994.

Crooks, S. A. and Gray, L. J.: Characterization of the 11-Year Solar Cycle Using a Multiple Regression Analysis of the ERA-40 Dataset, J. Climate, 18, 996-1015, 2005.

Dikty, S., Weber, M., von Savigny, C., Rozanov, A., Sonkaew, T., and Burrows, J. P.: Modulations of the 27-day solar rotation signal in stratospheric ozone from SCIAMACHY (2003-2008), J. Geophys. Res., 115, D00I15, doi:10.1029/2009JD012379, 2010.

Giorgetta, M. A., Manzini, E., Roeckner, E., Esch, M., and Bengtsson, L.: Climatology and Forcing of the QBO in MAECHAM5, J. Climate, 19, 3882-3901, 2006.

Gruzdev, A. N., Schmidt, H., and Brasseur, G. P.: The effect of the solar rotational irradiance variation on the middle and upper atmosphere calculated by a three-dimensional chemistry-climate model, Atmos. Chem. Phys., 9, 595-614, doi:10.5194/acp-9595-2009, 2009.
Haefele, A., Hocke, K., Kämpfer, N., Keckhut, P., Marchand, M., Bekki, S., Morel, B., Egorova, T., and Rozanov, E.: Diurnal changes in the middle atmospheric $\mathrm{H}_{2} \mathrm{O}$ and $\mathrm{O}_{3}$ : Observations in the Alpine region and climate models, J. Geophys. Res., 113, D17303, doi:10.1029/2008JD009892, 2008.

Haigh, J. D.: The effects of solar variability on the Earth's climate, Philos. T. Roy. Soc. Lond. A, 361, 95-111, 2003.

Hood, L. L.: Effects of solar UV variability on the stratosphere, Solar Variability and Its Effects on Climate, Geophys. Monogr., 141, 283-303, 2004.

Hood, L. L. and Zhou, S.: Stratospheric effects of 27-day solar ultraviolet variations: An analysis of UARS MLS ozone and temperature data, J. Geophys. Res., 103, 3629-3638, 1998.

Huang, F. T., Mayr, H., Russel III, J. M., Mlynczak, M. G., and Reber, C. A.: Ozone diurnal variations and mean profiles in the mesosphere, lower thermosphere, and stratosphere, based on measurements from SABER on TIMED, J. Geophys. Res., 113, A04307, doi:10.1029/2007JA012739, 2008.

Huang, F. T., Mayr, H. G., Reber, C. A., Russel III, J. M., Mlynczak, M. G., and Mengel, J. G.: Ozone quasi-biennial oscillations (QBO), semiannual oscillations (SAO), and correlations with temperature in the mesosphere, lower thermosphere, and stratosphere, based on measurements from SABER on TIMED and MLS on UARS, J. Geophys. Res., 113, A01316, doi:10.1029/2007JA012634, 2008.

Kinnison, D. E., Brasseur, G. P., Walters, S., Garcia, R. R., Marsh, D. R., Sassi, F., Harvey, V. L., Randall, C. E., Emmons, L., Lamarque, J. F., Hess, P., Orlando, J. J., Tie, X. X., Randel, W., Pan, L. L., Gettelman, A., Granier, C., Diehl, T., Niemeier, U., and Simmons, A. J.: Sensitivity of chemical tracers to meteorological parameters in the MOZART-3 chemical transport model, J. Geophys. Res., 112, D20302, doi:10.1029/2006JD007879, 2007.

Llewellyn, E. J., Lloyd, N. D., Degenstein, D. A., Gattinger, R. L., Petelina, S. V., Bourassa, A. E., Wiensz, J. T., Ivanov, E. V., McDade, I. C., Solheim, B. H., McConnell, J. C., Haley, C. S., von Savigny, C., Sioris, C. E., McLinden, C. A., Griffioen, E., Kaminski, J., Evans, W. F. J., Puckrin, E., Strong, K., Wehrle, V., Hum, R. H., Kendall, D. J. W., Matsushita, J., Murtagh, D. P., Brohede, S., Stegman, J., Witt, G., Barnes, G., Payne, W. F., Piché, L., Smith, 30 K., Warshaw, G., Deslauniers, D.-L., Marchand, P., Richardson, E. H., King, R. A., Wevers, I., McCreath, W., Kyölä, E., Oikarinen, L., Leppelmeier, G. W., Auvinen, H., Mégie, G., Hauchecorne, A., Lefévrel, F., de La Nöe, J., Ricaud, P., Frisk, U., Sjoberg, F., von Schéele, F., and Nordh, L.: The OSIRIS instrument on the Odin spacecraft, Can. J. Phys., 82, 411-422, doi:10.1139/P04-005, 2004.

Manzini, E., Giorgetta, M. A., Esch, M., Kornblueh, L., and Roeckner, E.: Sensitivity of the Northern Winter Stratosphere to Sea Surface Temperature Variations: Ensemble Simulations with the MAECHAM5 Model, J. Climate, 19, 3863-3881, 2006.

Marsh, D., Smith, A., and Noble, E.: Mesospheric ozone response to changes in water vapor, J. Geophys. Res., 108(D3), 4109, doi:10.1029/2002JD002705, 2003.

Marsh, D. R., Skinner, W. R., Marshall, A. R., Hays, P. B., Ortland, D. A., and Yee, J.-H.: High Resolution Doppler Imager observations of ozone in the mesosphere and lower thermosphere, J. Geophys. Res., 107(D19), 4390, doi:10.1029/2001JD001505, 2002. 
Marsh, D. R., Garcia, R. R., Kinnison, D. E., Boville, B. A., Sassi, F., Solomon, S. C., and Matthes, K.: Modelling the whole atmosphere response to solar cycle changes in radiative and geomagnetic forcing, J. Geophys. Res., 112, D23306, doi:10.1029/2006JD008306, 2007.

Mlynczak, M. G., Marshall, B. T., Martin-Torres, F. J., Russel III, J. M., Thompson, R. E., Remsberg, E. E., and Gordley, L. L.: Sounding of the Atmosphere using Broadband Emission Radiometry observations of daytime mesospheric $O_{2}\left({ }^{1} \Delta\right)$ $1.27 \mu \mathrm{m}$ emission and derivation of ozone, atomic oxygen, and solar and chemical energy deposition rates, J. Geophys. Res., 112, D15306, doi:10.1029/2006JD008355, 2007.

Mukhtarov, P., Pancheva, D., and Andonov, B.: Global structure and seasonal and interannual variability of the migrating diurnal tide seen in the SABER/TIMED temperatures between 20 and $120 \mathrm{~km}$, J. Geophys. Res., 114, A02309, doi:10.1029/2008JA013759, 2009.

Remsberg, E. E., Gordley, L. L., Marshall, B. T., Thompson, R. E., Burton, J., Bhatt, P., Harvey, V. L., Lingenfelser, G., and Natarajan, M.: The Nimbus 7 LIMS version 6 radiance conditioning and temperature retrieval methods and results, J. Quant. Spectrosc. Ra., 86, 395-424, doi:10.1029/2006JD007339, 2004.

Remsberg, E. E., Marshall, B. T., Garcia-Comas, M., Krueger, D., Lingenfelser, G. S., Martin-Torres, J., Mlynczak, M. G., Russel III, J. M., Smith, A. K., Zhao, Y., Brown, C., Gordley, L. L., Lopez-Gonzales, M. J., Lopez-Puertas, M., She, C.-Y., Taylor, M. J., and Thompson, R. E.: Assesment of the quality of the Version 1.07 temperature-versus-pressure profiles of the middle atmosphere from TIMED/SABER, J. Atmos. Res., 113, D17101, doi:10.1029/2008JD010013, 2008.

Ricaud, P., de La Noë, J., Connor, B. J., Froidevaux, L., Waters, J.W., Harwood, R. S., MacKenzie, I. A., and Peckham, G. E.: Diurnal variability of mesospheric ozone as measured by the UARS microwave limb sounder instrument: Theoretical and groundbased validations, J. Geophys. Res., 101, 10077-10089, 1996.

Rong, P. P., Russell III, J. M., Mlynczak, M. G., Remsberg, E. E., Marshall, B. T., Gordley, L. L., and Lopez-Puertas, M.: Validation of TIMED/SABER v1.07 ozone at $9.6 \mu \mathrm{m}$ in the altitude range 15-70 km, J. Geophys. Res., 114, D04306, doi:10.1029/2008JD010073, 2008.
Russel III, J. M., Mlynczak, M. G., Gordley, L. L., Tansock Jr., J. J., and Esplin, R. W.: Overview of the SABER experiment and preliminary calibration results, Proc. SPIE, 3756, doi:10.1117/12.366382, 1999.

Ruzmaikin, A., Santee, M. L., Schwartz, M. J., Froidevaux, L., and Pickett, H. M.: The 27-day variations in stratospheric ozone and temperature: New MLS data, Geophys. Res. Lett., 34, L02819, doi:10.1029/2006GL02819, 2007.

Schmidt, H., Brasseur, G. P., Charron, M., Manzini, E., Giorgetta, M. A., Diehl, T., Fomichev, V. I., Kinnison, D., Marsh, D., and Walters, S.: The HAMMONIA Chemistry climate model: Sensitivity of the mesopause region to the 11-year solar cycle and $\mathrm{CO}_{2}$ doubling, J. Climate, 16(19), 3903-3931, 2006.

Schneider, N., Selsis, F., Urban, J., Lezeaux, O., de LaNoë, J., and Ricaud, P.: Seasonal and Diurnal Variations: Observations and Modeling, J. Atmos. Chem., 50, 25-47, 2005.

Sinnhuber, M., Burrows, J. P., Chipperfield, M. P., Jackman, C. H., Kallenrode, M.-B., Künzi, K. F., and Quack, M.: A model study of the impact of magnetic field structure on atmospheric composition during solar proton events, Geophys. Res. Lett., 30(15), 1818, doi:10.1029/2003GL017265, 2003.

Smith, A. K., Marsh, D. R., Russel III, J. M., Mlynczak, M. G., Martin-Torres, F. J., and Kyrölä, E.: Satellite observations of high nightime ozone at the equatorial mesopause, J. Geophys. Res., 113, D17312, doi:10.1029/2008JD010066, 2008.

Soukharev, B. E. and Hood, L. L.: Solar cycle variation of stratospheric ozone: multiple regression analysis of long-term satellite data sets and comparisons with models, J. Geophys. Res., 111, D20314, doi:10.1029/2006JD007107, 2006.

Vaughan, G.: Mesospheric ozone - theory and observation, Q. J. Roy. Meteor. Soc., 110, 239-260, 1984.

Zhang, X., Forbes, J. M., Hagan, M. E., Russel III, J. M., Palo, S. E., Mertens, C. J., and Mlynczak, M. G.: Monthly tidal temperatures 20-120 km from SABER/TIMED, J. Geophys. Res., 111, A10S08, doi:10.1029/2005JA011504, 2006.

Zhu, X., Yee, J.-H., and Talaat, E. R.: Effect of dynamicalphotochemical coupling on oxygen airglow emission and implications for daytime ozone retrieved from $1.27 \mu \mathrm{m}$ emission, J. Geophys. Res., 112, D20304, doi:10.1029/2007JD008447, 2007. 